\title{
The Harbinger, truth or fiction?
}

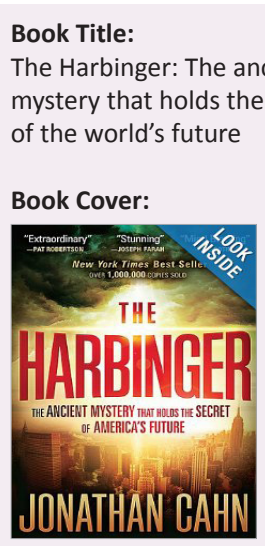

Author:

Jonathan Cahn

ISSN:

978-1-61638-611-5

\section{Publisher:}

Lake Mary: FrontLine

Charisma House Book Group, 2011, R153.00*

*Book price at time of review -

\section{Review title:}

The Harbinger, truth or fiction?

Reviewer:

Raymond Potgieter ${ }^{1}$

\section{Affiliation:}

${ }^{1}$ Faculty of Theology,

Northwest University,

South Africa

Email:

ray@csmdist.com

Postal address:

PO Box 19491, Noordbrug

2522, South Africa

How to cite this book review: Potgieter, R., 2013, 'The Harbinger, truth or fiction?', In die Skriflig/In Luce Verbi 47(1), Art. \#1700, 2 pages. http://dx.doi.org/10.4102/ ids.v47i1.1700

Read online:
Rabbi Jonathan Cahn's The Harbinger falls into the category of Christian mystery, claiming to unlock secrets hidden from the Christian community, in this case for millennia. In some sense it is similar to Dan Brown's The Da Vinci Code in that it follows a story with a message unlocking it as the plot unfolds. The message comes as a thunderclap - supposedly revealing momentous consequences both for the United States of America and the whole world (p. v). A steep claim indeed justified by present-day international American influence. But what is the message that has been heard on CBN's The 700 Club, by President Obama and more (key in 'harbinger' on youtube. com for any number of videos featuring Jonathan Cahn presenting The Harbinger message)?

The key lies partly in the title. The word 'harbinger' means to foreshadow and in this instance it concerns a particular message. A further menacing foreboding is posited of what will transpire should response to the message not equate to Cahn's interpretation of some passages of the Bible underlying the message. Generally the first Christian response to such claims is the inevitable question of credibility through asking: Is it a biblical message and is it applicable today?

Cahn's message draws its substance from an underlying message of Isaiah 9:10-11, claiming that it is applicable to America. Other select passages from the Old Testament in play are in particular Isaiah 10:5-7; 12-16 and 12:10. The storyline follows Nouriel Kaplan and a meeting with Ana Goren (publisher) which simply serves as a reasonable setting for developing the hidden story of the book. Nouriel relates his story to Ana hoping she will publish it. His story is about meeting with a prophet who entrusts nine seals (graphically portrayed as a breach, terrorist, fallen bricks, tower, gazit stone, a sycamore, the erez tree, utterance and the prophecy), one at a time to him, which he must interpret (pp. 25-124). It soon becomes clear to Nouriel that he is tracing the fall of Israel (northern kingdom) and soon the events of 9/11 are related to these ancient seals. By elaborating on that event and events thereafter the metaphorical clanging of alarms begins to be discerned so as 'to wake up a sleeping nation to change its course, to save it from judgment' (p. 30). A pattern is discerned from Isaiah 12:10 which apparently may be clearly imposed upon the unfolding of historical American events (p. 124) and so by implication the same fate suffered by Israel awaits America. What makes fascinating reading is the correspondence Cahn sees between events in ancient Israel in response to prophetic warnings and that of present-day America's response to $9 / 11$. Though the seals describe calamity they actually continue their messages of warning to the nation (p. 126). For instance, Cahn makes much of political statements confidently uttered by politicians (President Obama) oblivious of their offence to God by excluding God from their confident agenda in rebuilding and strengthening the American nation.

But the mystery deepens. Nouriel is inducted into the mystery, that not only are the seals harbingers of warnings but spell destruction, threatened by the judgment of God (p. 128). In the second part of the book Cahn resorts frequently to chosen passages from commentators (cf. p. 128) of his choosing who emphasise what happens when prophetic warnings are taken lightly or even ignored. The collapse of Wall Street is for instance related to Jeremiah 35:4 referring to the historical beginnings of trade along a wall on Manhatten Island to eventually become the famous Wall Street (pp. 146-147). Another obvious infringement is President Obama's boosting his nation's confidence with the words 'We will rebuild' repeated again and again (pp. 184-185). Taken by Cahn as unconscious 'prophetic fulfilment declarations by political leaders of a sufficiency without God, even leads to relating warnings to a time-scale' (p. 199). Cahn reminds the nation that eternal order and rule stem from God and that order authorises any way forward, not the idealisms of a president and his nation (p. 215). In a comparison of the collapse of Israel and later the capitulation of Judah, Cahn interprets the disregard of the signs and warnings once given to Israel by the prophets, as evidence that divine protection has been removed. Inevitably Judah followed the same pattern of collapse in 586 BCE (p. 220). As a final nail in the coffin to legitimise his message, Cahn identifies Nouriel as sharing the same name, Baruch, with the prophet Jeremiah's scribe, suggesting that Nouriel now has the same duty to make these prophetic warnings known to America and the world (p. 246).

Copyright: (c) 2013. The Authors. Licensee: AOSIS OpenJournals. This work is licensed under the Creative Commons Attribution License. 
Thus to answer the question: Is it biblical? There is no doubt that Cahn is a zealous pastor and deeply concerned about his country. Nor is there any doubt that he understands the Bible passages in question and while remaining within the context, the Old Testament is to be trusted. But to venture outside of its pages by extrapolating its truths and to equate them as being a prophetic commentary on events in America, proves to be a risky matter despite his claim that 'the story is real' (p. 7). Proven hermeneutics must guide interpretation and not the framework of a story, for that is what this book is, a story. Patterns of destruction of nations throughout humankind's history reveal some degree of similarity of the 'signs or seals' to that of Israel and Judah. Nor does Cahn's claim that America is God's chosen nation (pp. 206-207) hold biblical water. That would redefine our Christian understanding of the church. He would do well to see that the hope of the United States of America and the world is God and the unfolding of his plan; not a specific country regardless of coincidental signs which could be interpreted, as Cahn does, to have harbinger quality. From the Church's perspective biblical prophecy pertains to the Kingdom of God and the world, not a single nation.

Despite these worrisome observations there is no doubt that his story-like message finds particular appeal beyond his congregation, said to comprise of Jews and Gentiles, who revel in being inducted into the 'mysteries' of God's word. The book's value lies in its pastoral call to national and international repentance from sin and a turning to God. 